П. Я. Цідило, судовий експерт сектору трасологічного обліку

відділу криміналістичних видів досліджень,

Львівський науково-дослідний експертно-

криміналістичний центр МВС України, м. Львів

ORCID: https://orcid.org/0000-0003-0668-7184

\title{
ТРАСОЛОГІЧНЕ ДОСЛІДЖЕННЯ СЛІДІВ ТЕРМІЧНОГО ОБРОБЛЕННЯ НА ПОЛІЕТИЛЕНОВИХ ВИРОБАХ ТА ІДЕНТИФІКУВАННЯ ПРИЛАДІВ, ЩО ЇХ ЗАЛИШИЛИ, ЯК НОВИЙ РІЗНОВИД СУДОВОЇ ТРАСОЛОГІЧНОЇ ЕКСПЕРТИЗИ
}

\begin{abstract}
Meта статті полягає в обгрунтуванні доцільності започаткування трасологічного дослідження слідів термічного оброблення на поліетиленових виробах та ідентифікування приладів, що їх залишили, як нового різновиду судової трасологічної експертизи. Методологія. Достовірність отриманих результатів і висновків забезпечено використанням загальнологічних (загальнонаукових) та спеціальних методів пізнання. Діалектичним методом обрано об'єкт і предмет дослідження, обгрунтовано його мету та завдання; методом аналізу та узагальнення здійснено необхідні обгрунтування на основі теорії зварювання полімерних плівок; структурно-функціональним методом вивчено механізм утворення швів на плівкових матеріалах; експериментальним методом виготовлено експериментальні зразки слідів термічного оброблення; із застосуванням методу мікроскопічного дослідження вивчено сліди термічного оброблення на об'єктах дослідження та експериментальних зразках і їх структуру, за результатами якого встановлено збіжні окремі (ідентифікаційні) ознаки у слідах. Наукова новизна. Теоретично обгрунтовано, методологічно розроблено і в конкретному експертному провадженні експериментально апробовано новий різновид трасологічної експертизи. Висновки. Аргументовано на основі дослідження сучасних особливостей кримінальних правопорушень у сфері обігу наркотичних засобів та психотропних речовин у частині їх маскування і транспортування, аналізу основних положень теорії зварювання плівкових матеріалів, виготовлених із пластичних мас, і механізму утворення швів на них, а також реаліями сьогодення необхідність вдосконалення трасологічної експертизи. Доведено в результаті дослідження зразків слідів термічного оброблення на пакувальних матеріалах конкретного кримінального провадження та наданого на дослідження приладу, що впровадження в експертну практику нового різновиду трасологічних досліджень розширить можливості розкриття злочинів у частині ідентифікування пристроїв, які залишили сліди термічного оброблення, і підвищить потенціал однієї з основоположних галузей криміналістики - трасології. Узагальнено досвід проведення трасологічної експертизи в частині дослідження слідів термічного оброблення на поліетиленових виробах, визначення їх походження та ідентифікування конкретних пристроїв, що залишили ці сліди, а також висловлено пропозиції, що можуть стати основою відповідних методичних рекомендацій для судових експертів експертних установ і працівників правоохоронних органів.

Ключові слова: судова трасологічна експертиза; сліди термічного оброблення; поліетиленові вироби; сліди термічного оброблення на поліетиленових виробах; ідентифікування приладів, що залишили сліди термічного оброблення; термоконтактне та термоімпульсне зварювання; зварні шви; наркотичні засоби.
\end{abstract}

\section{Вступ}

У реаліях соціально-економічних змін в країні, серед характерних рис яких відчутний рівень безробіття, криміногенна ситуація чинить небезпечний антисоціальний вплив на суспільство. 3окрема, останніми роками значно зросла загальна кількість кримінальних правопорушень у сфеpi обігу наркотичних засобів та психотропних речовин (Zvit shchodo narkotychnoi ta alkoholnoi sytuatsii, 2020; Serdiuk, Bazyma, \& Shcherbakova, 2020; Turianskyi, 2020), маскування і транспортування яких щороку дедалі більше вдосконалюється (Nykyforchuk, 2019). 3'являються нові канали розповсюдження наркотичних засобів через інтернет-сайти та чат-боти, поштові та контейнерні перевезення. Доволі різноманітні й способи приховування небезпечних переправлень: поштовий зв'язок, електроприлади, автомобілі тощо. Правопорушники вигадують дедалі нові способи їх пакування, маскування, транспортування, що, як відомо, $є$ базовою складовою їх розповсюдження (Rudnytskyi, 2017).

Серед найпоширеніших видів пакування наркотичних засобів і психотропних речовин для транспортування $€$ ïх пакування у поліетиленові пакети, краї яких запаюють спеціальними імпульсними зварювачами, що забезпечує герметичність упакування, зменшує рівень запахів і випарів (Kryvoshei, \& Khalaidzhi, 2019). Тому дедалі актуальнішим стає пошук шляхів удосконалення трасологічної експертизи в означеному напрямі.

Питання теорії трасології й трасологічної експертизи розробляли, зокрема, В. Є. Бергер, Г. Л. Грановський, Є. І. Зуєв, Ю. Г. Корухов, 
Л. К. Литвиненко, Н. П. Майліс, С. М. Потапов, В. М. Прищепа, М. В. Салтевський, М. Я. Сегай, А. О. Фокіна, Б. І. Шевченко, створивши «струнку наукову галузь знань - криміналістичне вчення про сліди» (Kofanov, Voloshyn, \& Litvinova, 2010, s. 6).

Наразі науковці серед інших, що стосуються нашої проблематики, висвітлюють питання технологічних особливостей перероблення сумішей полімерів на основі надвисокомолекулярного поліетилену (Bratychak, Chopyk, \& Zemke, 2018); товарознавчої експертизи полімерних пакетів (Lysenko, 2019); теплофізичних характеристик формувального розчину біодеградабельного їстівного покриття / плівки (Shulha, Ivanov, Lystopad, \& Mazurenko, 2019); феромагнітних полімерних дисперсій на основі метакрилових естерів - вплив параметра розчинності композицій на закономірності одержання (Semeniuk, Skorokhoda, \& Dudok, 2020); класифікації слідів, їх пошуку (Zakurlaev, 2020; Zulfuqorov, 2020); особливості експертного дослідження слідів (Chernov, Holomisiuk, \& Yevsieiev, 2019; Hrabovskyi, \& Oparii, 2020); важливості судових доказів для прийняття кримінальних процесуальних рішень (Ling, Kaplan, \& Berryessa, 2021).

Окремі аспекти трасологічних досліджень слідів термічного оброблення на виробах із полімерів вивчали О. Г. Волошин, А. В. Кофанов, О. В. Літвінова, Н. П. Майліс та ін. Проте сьогодні бракує грунтовних досліджень слідів термічного оброблення на поліетиленових виробах за результатами виявлення групової належності, ідентифікування приладів, які залишили ці сліди. Тому є потреба комплексного дослідження означеної у статті проблеми.

\section{Мета й завдання дослідження}

Мета статті - обгрунтувати доцільність започаткування трасологічного дослідження слідів термічного оброблення на поліетиленових виробах та ідентифікування приладів, що їх залишили, як нового різновиду судової трасологічної експертизи.

Для досягнення цієї мети потрібно виконати такий комплекс логічно пов'язаних завдань:

з'ясувати необхідність вдосконалення трасологічної експертизи на основі дослідження сучасних особливостей кримінальних правопорушень у сфері обігу наркотичних засобів та психотропних речовин у частині їх маскування і транспортування, аналізу основних положень теорії зварювання плівкових матеріалів, виготовлених із пластичних мас, і механізму утворення швів на них;

дослідити зразки слідів термічного оброблення на пакувальних матеріалах конкретного кримінального провадження та наданого для дослідження приладу, при цьому виготовити експериментальні зразки, провести мікроскопічне дослідження слідів термічного оброблення на наданих пакувальних матеріалах, порівняти їх 3 експериментальними зразками, а також здійснити ідентифікування приладу, який їх залишив;

узагальнити отримані результати, сформулювати висновки і пропозиції.

\section{Виклад основного матеріалу}

У межах досудового розслідування працівники правоохоронних органів після виявлення та вилучення наркотичних засобів, які були запаковані у поліетиленові вироби з герметичними краями запаювання, проводять обшуки у підозрюваних, під час яких можуть виявлятися спеціальні пристрої для запаювання (зварювання) поліетиленових виробів. У такому разі може постати запитання: чи залишені сліди термічного оброблення (зварні шви), фактично наявні на вилучених поліетиленових пакетах, виявленим спеціальним пристроєм для спаювання (зварювання). I хоча означений різновид трасологічної експертизи не належить до найпоширеніших, але проведення таких досліджень сприятиме створенню більш вагомого підгрунтя для бази доказів у кримінальних провадженнях. Тому спершу проаналізуймо основні властивості полімерних виробів та їх характерні ознаки під час здійснення процесу запаювання (Bratychak, Chopyk, \& Zemke, 2018).

Практика засвідчує, що майже половина пакувальних виробів, які випускає промисловість, складається 3 кількох деталей, з’єднаних в один виріб. При цьому послуговуються і таким чи не найпоширенішим способом міцного з'єднання, як зварювання, що полягає у нероз'ємному з'єднанні елементів шляхом хімічного чи дифузійного з'єднування макромолекул полімерних матеріалів, коли між з’єднуваними поверхнями зникає межа поділу і створюється структурний перехід між контактними поверхнями полімерів. Проте зварюванню піддаються не всі види полімерів.

Полімер може перебувати у склоподібному, високоеластичному і в'язкоплинному стані. Перехід з одного стану в інший відбувається в певному діапазоні температур. Дифузійно-реологічний процес взаємодії зварюваних поверхонь найбільш ефективно реалізується у в'язкоплинному стані матеріалу.

Взаємодія зварюваних поверхонь заснована на виникненні хімічних зв'язків між полімерними матеріалами, а суттю будь-якої хімічної реакції $\epsilon$, як відомо, розрив зв'язків у вихідних речовинах і виникнення нових. При цьому механізм активації має бути однаковий для різних їі режимів і полімерних матеріалів. Час, необхідний для активації, залежить 
від багатьох чинників, головні з них: амплітуда коливань; зусилля притискання; форма й властивості полімерного матеріалу, що активується.

Полімери, що не зварюються дифузійним способом (реактопласти, вулканізати), можна з'єднувати через хімічну взаємодію функціональних груп чи за допомогою присадного матеріалу, близького за активністю до зварюваних полімерів. При цьому підігрів (температура на поверхні зварюваного полімеру має відповідати температуpi в'язкоплинного стану), тиск (щільний контакт зварюваних поверхонь) й оптимальна тривалість зварювання або витримки створюють необхідні умови для зварювання, а присадні матеріали сприяють активації реакційно-спроможних груп.

Зварюваність полімерів кількісно оцінюють енергією активації в'язкого стану, що характеризує молекулярно-масовий розподіл, розгалуженість молекулярних ланцюгів і полярність молекулярних ланок.

Для виготовлення плівкових пакувань застосовують поліетиленові, поліпропіленові, полістирольні, полівінілхлоридні та інші плівки.

За здатністю до зварювання вирізняють чотири групи полімерів:

неорієнтовані термопласти (з енергією активації в'язкої плинності значно меншою, ніж енергія руйнування хімічного зв'язку, із широким температурним інтервалом в'язкоплинного стану, в'язкістю розплаву в інтервалі температур зварювання 102-105 Па.с), що добре зварюються різними методами в інтервалі від температури плинності до температури деструкції. Найкраще зварюються поліолефіни - поліетилени високого та низького тиску і поліпропілени, які мають низьку енергію активації в'язкої плинності (46-53 кДж/моль), доволі низьку температуру плинності $\left(120-160^{\circ} \mathrm{C}\right)$, широкий інтервал температур в'язкоплинного стану (понад $\left.50^{\circ} \mathrm{C}\right)$, порівняно низьку в'язкість розплаву;

термопласти (з енергією активації в'язкої плинності, близькою до енергії руйнування хімічного зв'язку макромолекули, із вузьким температурним інтервалом в'язкоплинного стану (менше $50{ }^{\circ} \mathrm{C}$ ) або порівняно високою в'язкістю розплаву, що становить 107-108 Па.с), які погано зварюються плавленням, кожний випадок потребує оптимальних технологічних режимів і способів. До цієї найбільш численної групи (полівінілхлорид, полівініліденхлорид, пентапласт, поліетилентерефталат, деякі фторопласти тощо) належать орієнтовані напівфабрикати з усіх відомих термопластів;

термопласти (енергія активації в’язкої плинності перевищує енергію хімічного зв'язку та в'язкість розплаву яких становить 10-1012 Па·с), що не можуть бути переведені у в'язкоплинний стан. Використовують, оскільки їхнє зварювання плавленням майже неможливе, високоеластичне деформування, а дифузійне зварювання здійснюють способом тривалого контакту поверхонь, що з'єднують (Fialko et al., 2018);

реактопласти й вулканізати, які неможливо з'єднати дифузійним зварюванням. Їх зварюють через хімічну взаємодію молекул полімерів, спровоковану нагріванням, тиском чи введенням у зону зварювання зшивального агента (Egorov, 2017).

Найпоширенішими пакувальними полімерними плівками $є$ :

поліпропіленова пакувальна плівка (ППП) полімерна обмотувальна плівка, яку використовують для упакування й транспортування вантажу (з найефективніших методів іï з'єднання: поліфузійне зварювання - найякісніший спосіб, за якого кінці зварюваних деталей будь-якої товщини з'єднують спеціальним приладом (автоматичним чи напівавтоматичним), нагрівають упродовж певного часу до потрібної температури та притискають один до одного з певним зусиллям, виконаний у такий спосіб шов достатньо міцний (80-90\% міцності базового матеріалу); застосування ручного екструдера, у гвинтовому каналі якого попередньо розплавляють присадний поліпропіленовий дріт і накладають на поверхню, яку потрібно з'єднати, при цьому на якості шва позначається неможливість забезпечити ручним екструдером постійну продуктивність і рівномірний тиск; зварювання пістолетом із гарячим повітрям (феном), що дає змогу підтримувати постійну температуру повітря, яке нагрівається, але через ручне керування операціями не гарантує стабільної якості зварного шва);

поліестерова пакувальна плівка (ПеПП) - використовують для обв'язування середньої ваги й важких вантажів під час їхнього складування й транспортування. 3'єднання ПеПП зварюванням забезпечує необхідну міцність шва (80-85 \% міцності матеріалу). Ручне зварювання відбувається завдяки взаємному тертю (віброзварюванню) шарів стрічки. Віброзварювання не здійснюють за низьких (нижче $5^{\circ} \mathrm{C}$ ) температур через невисоку міцність одержуваного шва. В автоматичних машинах для пакування може використовуватися термозварювання, що виключає обмеження, які виникають через низьку температуру середовища, і дає можливість упаковувати продукцію в неопалюваних цехах;

плівки з поліетилену високого та низького тиску (ППЕВТ, ППЕНТ) - пластичні, хімічно стійкі, водогазонепроникні, легко з'єднуються тепловим зварюванням з утворенням міцних швів;

поліетилентерефталатні плівки (ПЕТФП) досить міцні й жорсткі, тому на них наносять 
ППЕВТ, що, крім покращення зварного шва, забезпечує матеріалу вищі бар'єрні властивості до води та їі парів. ПЕТФП стійкіші до розриву і зношування, ніж плівки з поліолефінів (поліетилену) (Demura, 2001).

Найпоширенішими є такі технології зварювання полімерних матеріалів, як термоконтактна, термоімпульсна, зварювання ультразвуком, зварювання струмом високої частоти (СВЧ).

Термоконтактне зварювання полімерних матеріалів здійснюють нагрітим інструментом (рис. 1). При цьому зварювані поверхні, наприклад товстостінні полімерні вироби, переводять у в'язкоплинний стан контактним нагріванням металевим інструментом (обертові ролики, пластини, електропраски, кліщі, переносні преси), від якого також передається тиск, необхідний для з’єднання.
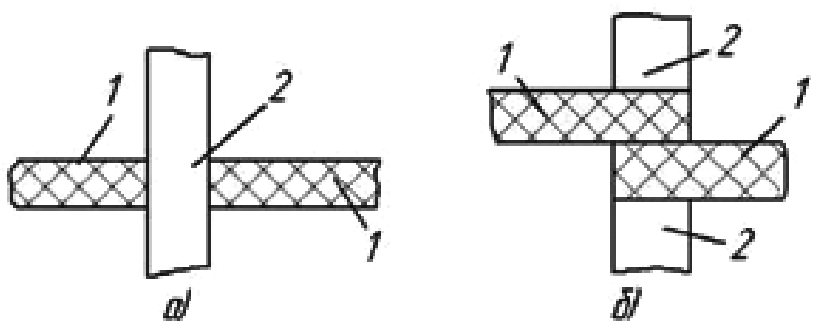

Рис. 1. Термоконтактне зварювання:

а) у стик; б) унапусток;

1 - зварювальні поверхні, 2 - нагрівальні плити

Термоконтактне зварювання у стик (рис. 1a) здійснюють із застосуванням нагрівальної плити (2) із вбудованими в неї електричними спіралями, яка щільно прилягає до зварювальних поверхонь (1), оплавляючи їх, після чого іï відводять, а поверхні стискають. Під час зварювання внапусток (рис. 2б) температура в зоні контакту має досягти температури в'язкоплинного стану полімеру (при цьому можливе утворення надлишкового тиску між поверхнями матеріалу та витиснення розплаву із зони зварювання, що призводитиме до відрізання зварюваного виробу вздовж шва).

Перевагами технології термоконтактного зварювання є дешевизна, надійність, легка контрольованість і регульованість, можливість зварювати майже всі полімерні плівки.

Термоімпульсне зварювання здійснюють непрямим нагріванням 3 одного чи обох боків зварювальних поверхонь, подаючи теплоту імпульсами від малоінерційного резистивного нагрівального інструмента, крізь який пропускають електричний струм (рис. 2).

Після вимикання електроенергії шов охолоджують під тиском. Цим способом з'єднують плівки товщиною до 0,5 мм. Перевагами зварювання $€$ сталість, відтворюваність, легкість регулювання теплового режиму, невеликі втрати теплоти, від-

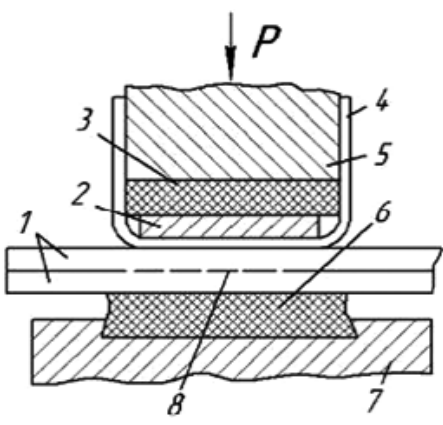

Рис. 2. Термоімпульсне зварювання:

1 - зварювальні плівки; 2 - нагрівальний інструмент; 3 - теплоелектроізоляційна прокладка;

4 - антиадгезійна прокладка; 5 - рухома частина зварювального пристрою; 6 - антиадгезійна підкладка;

7 - нерухома частина зварювального пристрою; 8 - зварний шов

сутність розігріву зовнішніх частин апарата, можливість зварювання термоусадочних плівок. До недоліків можна віднести тривалий цикл, циклічність роботи, частий вихід із ладу зварювальних елементів (Sidorov, Sivetskyi, Kolosov, Sokolskyi, \& Dudar, 2011).

Для проведення порівняльних досліджень і формування висновку щодо ототожнення конкретних предметів (приладів), якими залишені сліди трасологічного походження, керуємося вченням про ідентифікаційні ознаки, що становить один $з$ основних розділів теорії криміналістичної ідентифікації.

Ототожнення, тобто виділення відповідного матеріального утворення як єдиного цілого та відмежування від йому подібних, грунтується на уявному виокремленні характеристик об'єкта ідентифікації, які вважаються ідентифікаційними ознаками. Зазначені ознаки зумовлені природою матеріалу (речовини), походженням об'єкта, його призначенням, умовами експлуатації тощо. Формування цілісної системи ідентифікаційних ознак відбувається також у межах обставин розслідуваної події і визначається обставинами об’єднання будь-яких частин (компонентів) у ціле, умовами внутрішньої взаємодії частин (компонентів) у межах цілого, особливостями впливу на частини (компоненти) цілого зовнішніх чинників, специфічними наслідками розділення цілого на частини.

У криміналістиці ідентифікаційні ознаки класифікуються за різними підставами, але практичне значення мають лише окремі з них. Приміром, за характеристикою об'єктів ідентифікаційні ознаки поділяють на родові (підстави для встановлення належності об'єкта до певної категорії відповідно до визнаної у науці і техніці класифікаціï), групові (що характеризують спільність умов виникнення й існування об’єктів), індивідуальні або особливі, окремі (такі, що індивідуалізують об’єкт, дозволяють відрізнити його від інших). 
Стійкість системи ідентифікаційних ознак об’єкта зумовлюється переважно природою його субстанції та характером ï взаємодії з довколишнім середовищем. Ступінь значущості ідентифікаційних ознак об'єкта можна визначити на основі систематизації рецептурно-технологічних даних великої кількості однорідних об'єктів, безпосереднього вивчення технологічних процесів виготовлення відповідної продукції (Sidorov, Sivetskyi, Kolosov, Sokolskyi, \& Dudar, 2011).

Отже, для проведення досліджень щодо ототожнення слідів трасологічного походження на поліетиленових виробах необхідно проаналізувати низку ознак і характеристик таких виробів.

Так, для експерименту (з метою з'ясувати, чи ймовірно ідентифікувати конкретний пристрій, яким залишені сліди термічного оброблення (зварні шви) на поліетиленових виробах) використовували прозорі поліетиленові пакети, вилучені під час вжиття заходів щодо запобігання спробі перевезення незаконного вантажу через контрольно-пропускний пункт, а також імпульсний зварювач пакетів FRN 900, виявлений під час обшуків.

Для дослідження надано 20 прозорих поліетиленових пакетів зі слідами термічного оброблення у вигляді зварних швів. Вони мали розміри від 1560x454 до 1780x465 мм. Для зручності торцеві краї цих пакетів було відділено за допомогою інструмента, принцип дії якого полягає в зустрічному передавлюванні двох робочих губок із ріжучими кромками (рис. 3).

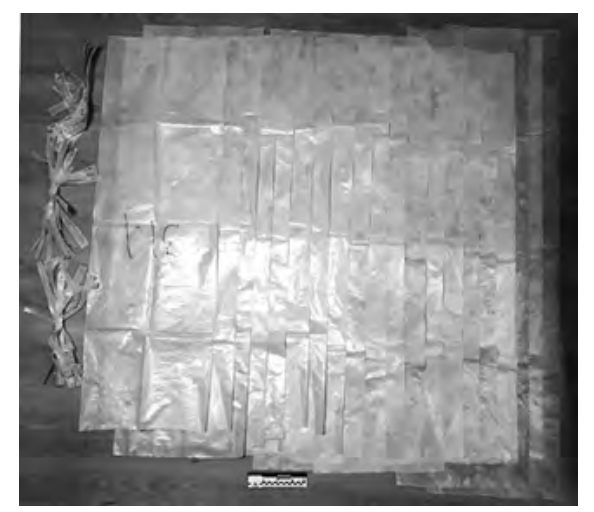

Рис. 3. Загальний вигляд прозорих поліетиленових пакетів, наданих для дослідження

Отримані 40 відрізків поліетиленових смужок розміром від 6x454 до 70x465 мм зі слідами дії термічного оброблення (зварних швів) для зручності дослідження пронумеровано (від № 1 до № 40) (рис. 4).

Візуально відрізки смужок виготовлені з однотипного прозорого поліетилену товщиною 0,07 мм в поперечному перерізі циліндричної форми. 3 трьох торців вони мають рівні прямолінійні краї, четвертий торцевий край хвилястий, у ви-

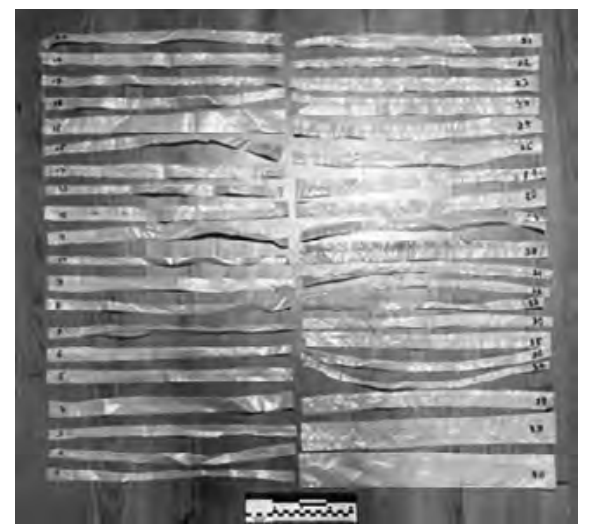

Рис. 4. Відрізки смужок із поліетиленових пакетів, наданих для дослідження, 3 позначеннями

гляді виступів і заглибин, часткових розривів матеріалу, що свідчить про дію стороннього предмета із загостреними робочими поверхнями. На всіх відрізках смужок як результат термічного оброблення наявні сліди у вигляді одного (на відрізках № 38, 39 і 40 - по два) поздовжнього прямолінійного зварного шва шириною від 1 до 2,5 мм. По всій поверхні відрізаних смужок заглибини у вигляді штрихів розміром від $1 \times 0,4$ до $2 \times 0,5$ мм, розміщені хвилястими, паралельними між собою рядами під кутом від 20 до $30^{\circ}$ відносно довжини відрізка, також проглядаються нашарування порошкоподібної речовини коричневого кольору.

Мікроскопічним дослідженням відрізків із використанням криміналістичної лупи 5-кратного збільшення та мікроскопа МСП-1 з'ясовано, що мікрорельєф швів на відрізках № 21-40 - у вигляді розміщених паралельними горизонтальними та вертикальними рядами виступів і заглибин, які в сукупності утворюють візерунок у вигляді сітки; № 1-20 - плоский і у вигляді прямолінійної смуги. На торцевих бокових краях швів опуклості й увігнутості, часткові звуження й розширення, що могли утворитися як у процесі слідоутворення (динамічністю слідоутворення, наявністю сторонніх елементів, частинок пилу), так і в процесі експлуатації слідоутворювальної поверхні чи інших сторонніх втручань (пошкоджень, ремонту тощо).

Наданий для дослідження пристрій загальним розміром $1150 \times 445 \times 100$ мм складається 3 робочого блока, що в корпусі, виготовленому з металу сірого кольору та покритому шаром сіро-голубої фарби, і робочих частин - металевої пластини (нерухомо зафіксованої в корпусі робочого блока, що в нижній частині пристрою) та важеля (прикріпленого до корпусу робочого блока за допомогою двох металевих заклепок i підпружиненого відповідною пружиною). Важіль працює за принципом зустрічного змикання 3 нижньою частиною за безпосередньої дії на нього незначного динамічного зусилля (натискання). На пластині та на важелі наявні зварювальні планки 
розміром 910x15 мм кожна. До робочого блока приєднаний електропровід чорного кольору довжиною 1650 мм, на зворотному торцевому кінці якого наявна вилка для приєднання до електромережі. На бічній стінці робочого блока регулятор із проставленими позначеннями від 1 до 8 . На відстані 10 мм угору від регулятора сигнальний діод, зовні покритий частково прозорим полімерним матеріалом червоного кольору. У верхній частині робочого блока ручка загальним розміром $70 x 30$ мм, виготовлена з металевого стрижня сірого кольору діаметром 8 мм. На поверхні пристрою наявні подряпини та потертості металу, що виникли в процесі його експлуатації, зберігання, транспортування тощо (рис. 5).
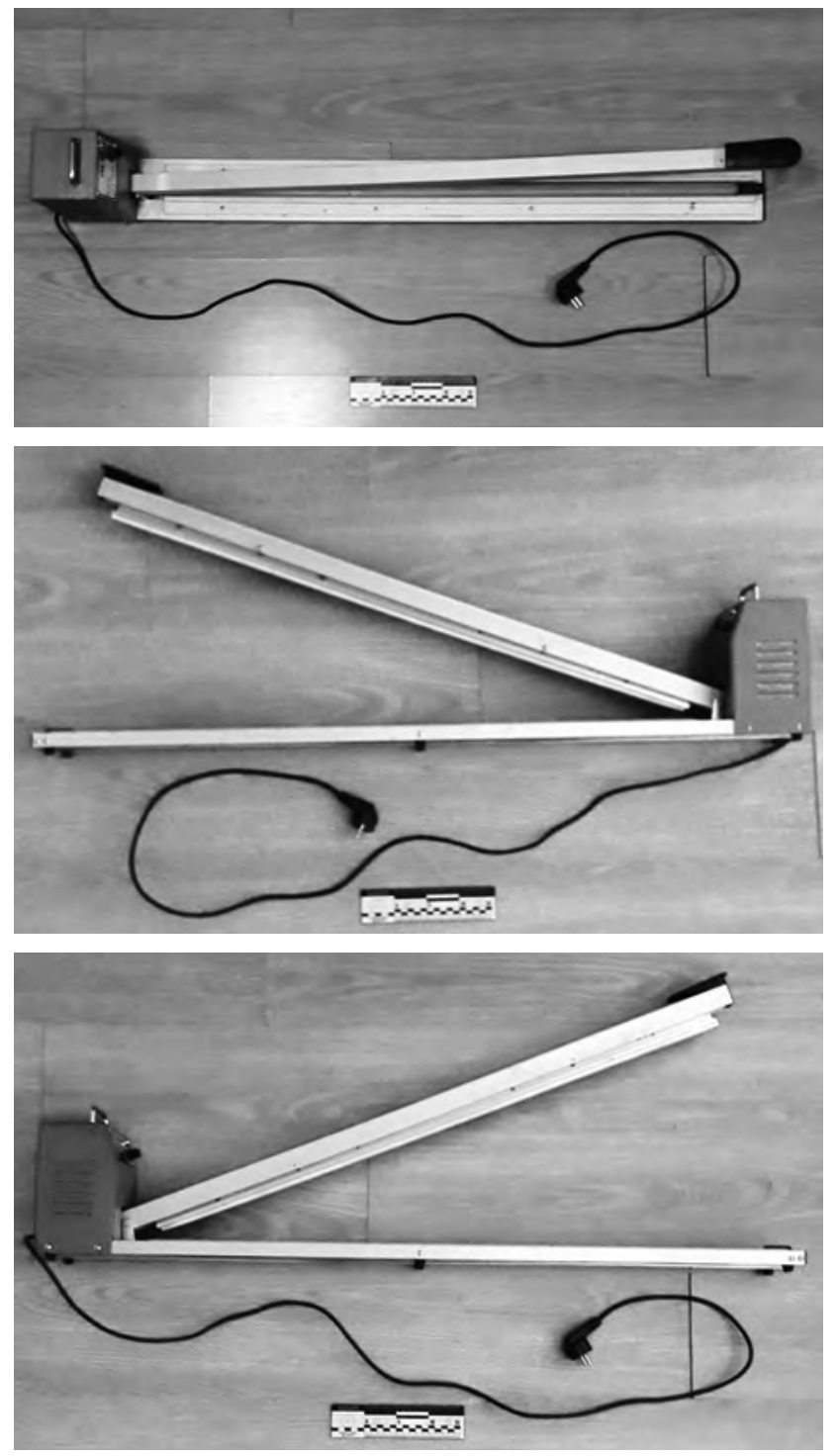

Рис. 5. Загальний вигляд (із трьох боків) пристрою, наданого для дослідження

Порівнюючи ознаки й будову досліджуваного пристрою та зразків пристроїв, поданих на офіційному сайті компанії IBK Техніка (TOV firma IVK Tekhnika, 2021), засвідчено збіг за загальними ознаками, будовою, маркувальними позначеннями з імпульсним зварювачем пакетів FRN 900.
Під час подальшого вивчення наданого для дослідження пристрою на зварювальній планці, що в нижній частині пристрою, виявлені пошкодження у вигляді розривів матеріалу верхнього покриття (антиадгезійної підкладки) розміром 23x16 мм (рис. 6a) і 9х4 мм (рис. 66), що виникли в результаті дії на матеріал стороннього зусилля і які можуть залишати характерні індивідуальні ознаки, якщо пристрій використовують за його первинним призначенням.

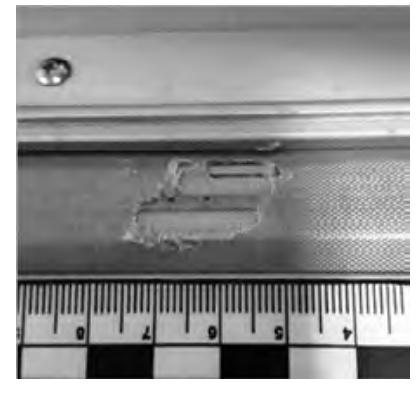

a

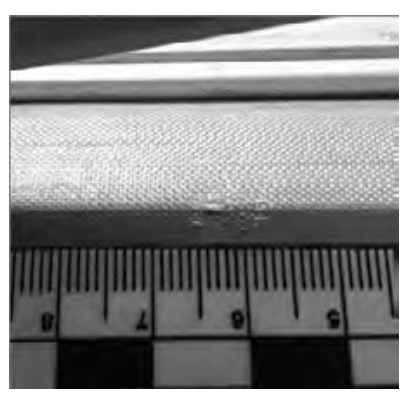

6
Рис. 6. Збільшений вигляд пошкоджень матеріалу верхнього покриття (антиадгезійної підкладки) на зварювальній планці, що на пластині в нижній частині пристрою, розміром $23 \times 16$ мм (а) і 9×4 мм (б)

Для вирішення питання, чи ймовірно ідентифікувати конкретний пристрій, яким залишені сліди термічного оброблення (зварні шви) на поліетиленових виробах, здійснювали візуальне порівняння таких слідів на відрізках прозорих поліетиленових смужок № 1-40, що були відділені від поліетиленових пакетів, наданих для дослідження, і на цих поліетиленових пакетах, використовуваних як вироби для виготовлення експериментальних слідів, які залишає наданий для дослідження імпульсний зварювач пакетів FRN 900, із застосуванням різних позицій регулятора та сили натискання (рис. 7).

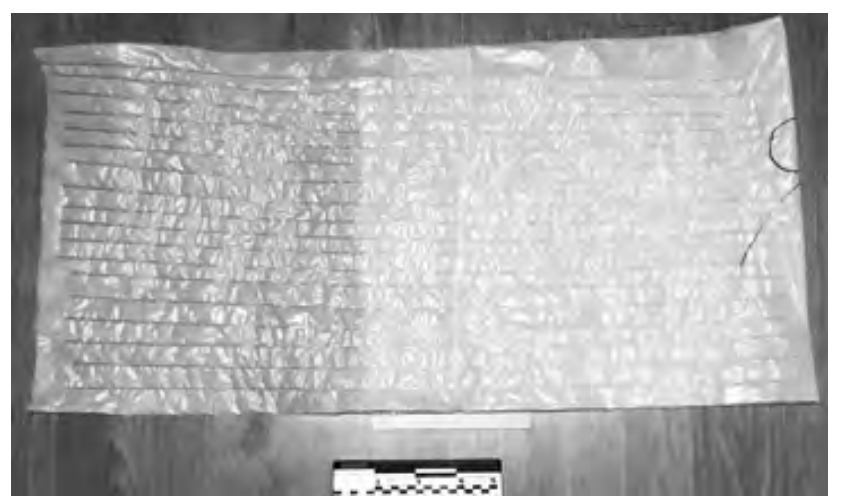

Рис. 7. Експериментальні зразки зварних швів, виготовлені за допомогою імпульсного зварювача пакетів FRN 900, наданого для дослідження

Як засвідчили результати порівняння, в усіх експериментальних слідах термічного оброблення (зварних швах) повно, чітко і стало відобразилися загальні та особливі ознаки мікрорельєфу зварювальної поверхні планки (антиадгезійної під- 
кладки) і важеля імпульсного зварювача пакетів FRN 900, які утворюють індивідуально характерний комплекс, властивий зварювальній поверхні наданого для дослідження пристрою. Зокрема, ідеться про виявлене на поверхні зварювальної планки на пластині в нижній частині пристрою пошкодження у вигляді розривів та часткової відсутності матеріалу верхнього покриття (антиадгезійної підкладки) розміром 23х16 мм, що не забезпечує достатнього покриття частини металевого тена та при зварюванні не утворює на цій ділянці характерного мікрорельєфу матеріалу покриття (антиадгезійної підкладки) (рис. 8). Ця ділянка при зварюванні повторюється на кожному з експериментальних зразків і $є$ індивідуальною, сталою особливістю, притаманною наданому для дослідження пристрою (рис. 9).

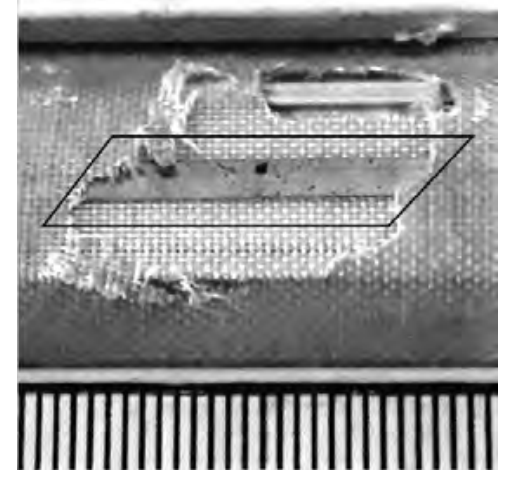

Рис. 8. Збільшений вигляд пошкодження верхнього покриття (антиадгезійної підкладки), виявленого на зварювальній планці в нижній частині пристрою

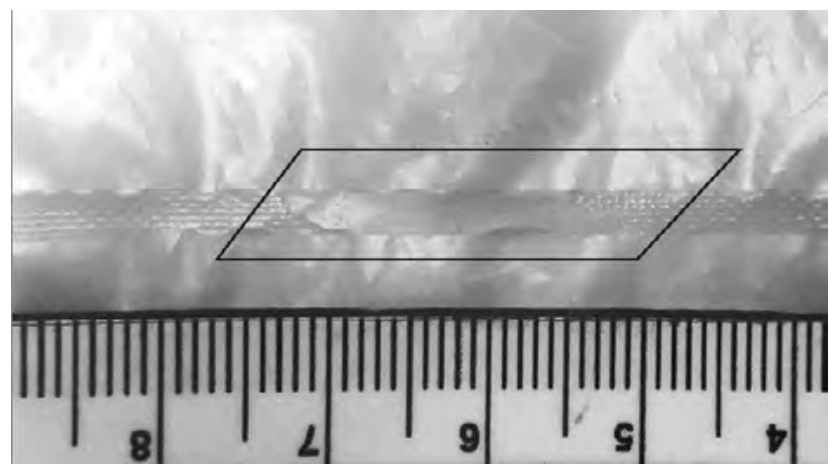

Рис. 9. Збільшений вигляд індивідуальної особливості, яку залишає антиадгезійна підкладка зварювальної планки в нижній частині пристрою, що відображається на експериментальних зразках зварювання

Виявлені ознаки дозволяють визнати отримані експериментальні сліди термічного оброблення (зварні шви) придатними для проведення за ними подальшого порівняльного дослідження.

При цьому звертають увагу на наявність / відсутність будь-яких змін у структурі зварних швів, зокрема характерного мікрорельєфу, викривлення його торцевих країв, опуклостей, увігнутостей тощо. у результаті подальшого порівняльного дослідження засвідчено збіг за загальними ознаками (формою, шириною шва, його мікрорельєфом) експериментальних слідів термічного оброблення (зварних швів), залишених наданим для дослідження імпульсним зварювачем пакетів FRN 900, що виникли внаслідок його експлуатації (пошкодження), з наданими для дослідження слідами термічного оброблення (зварними швами) на відрізках прозорих поліетиленових смужок № 3, 4, 6, 9, 12, 14, 16, 21, 27 і 29, відділених від поліетиленових пакетів, наданих для дослідження. Зокрема, на зазначених відрізках виявлено ділянку, на якій відсутній мікрорельєф, притаманний поверхні, що залишає антиадгезійна підкладка пристрою запаювання виробів із полімеру. Такі ділянки виявлено на всіх експериментальних слідах термічного оброблення (зварних швах), виготовлених за допомогою наданого для дослідження імпульсного зварювача пакетів FRN 900 (рис. 10).

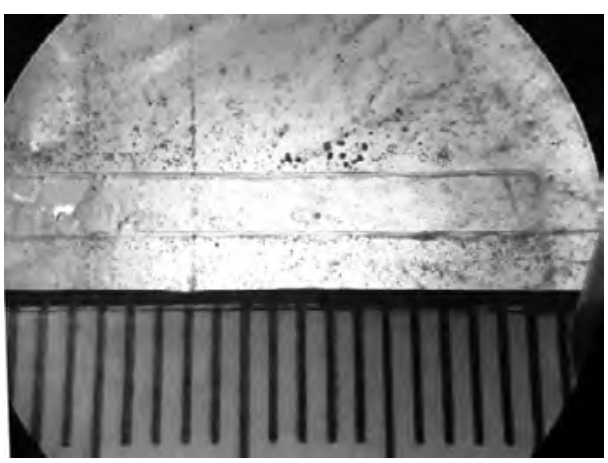

a

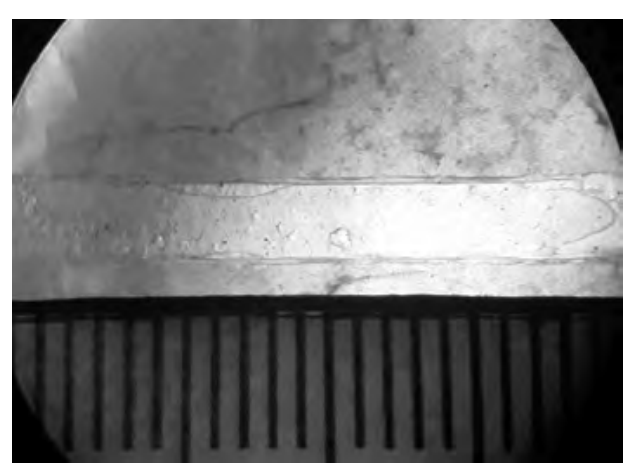

6

Рис. 10. Зображення збігів загальних ознак слідів термічного оброблення (зварних швів) на відрізку поліетиленової смужки (а) та на експериментальному зразку (б)

При цьому за допомогою мікроскопа МСП-1 виявлено збіг за окремими, індивідуальними ознаками експериментальних слідів термічного оброблення (зварних швів), залишених імпульсним зварювачем пакетів FRN 900, наданим для дослідження, що виникли внаслідок його експлуатації (пошкодження), зі слідами термічного оброблення (зварними швами) на відрізках прозорих 
поліетиленових смужок № 3, 4, 6, 9, 12, 14, 16, 21, 27 і 29, відділених від наданих для дослідження поліетиленових пакетів. Так, на краях виявленого сліду термічного оброблення (зварних швах) встановлено різні за довжиною характерні траси, вигини, які розміщуються в певному порядку і становлять індивідуальні особливості (ознаки) цього сліду. Зазначені ознаки повторюються в такому самому порядку в експериментальних слідах термічного оброблення (зварних швах), що є сталими ознаками i характерними винятково для зазначеного імпульсного зварювача пакетів FRN 900.

Для унаочнення збігів слідів термічного оброблення (зварних швів) на відрізках прозорих поліетиленових смужок № 3, 4, 6, 9, 12, 14, 16, 21, 27 і 29 здійснено розмічання збіжних окремих (індивідуальних) ознак з експериментальними зразками (зварними швами), виготовленими за допомогою імпульсного зварювача пакетів FRN 900, наданого для дослідження; обрано по одному сліду (досліджуваному та експериментальному) з огляду на їх однотипність за характером, формою, розмірами та індивідуальними ознаками (рис. 11).

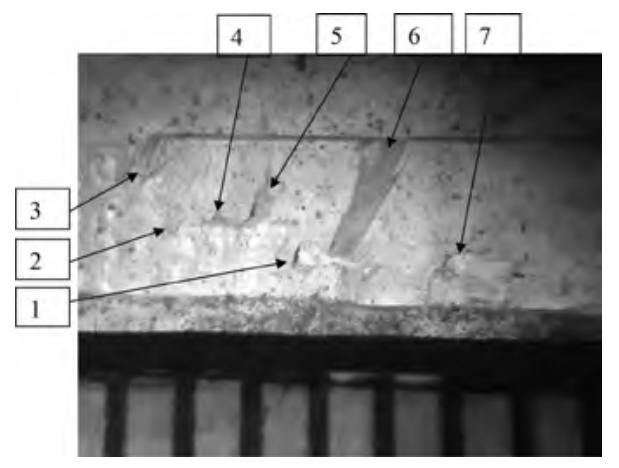

a

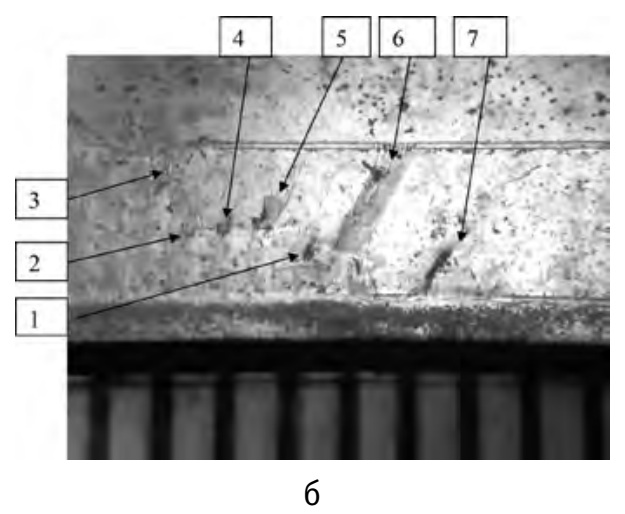

Рис. 11. Збіги окремих ідентифікаційних ознак слідів термічного оброблення (зварних швів) на відрізку одної із прозорих поліетиленових смужок (а) та одному із експериментальних зразків (б), залишеному наданим для дослідження імпульсним зварювачем пакетів FRN 900

Виявлені в процесі порівняльного дослідження збіжні загальні та окремі ознаки у своїй сукупності утворюють індивідуально-характерний стійкий, суттєвий комплекс ознак, достатній для висновку про те, що сліди термічного оброблення (зварні шви) на відрізках прозорих поліетиленових смужок № 3, 4, 6, 9, 12, 14, 16, 21, 27 і 29 залишені внаслідок зварювання пакетів за допомогою імпульсного зварювача пакетів FRN 900, наданого для дослідження.

При цьому сліди термічного оброблення (зварні шви) на відрізках прозорих поліетиленових смужок № 3, 4, 6, 9, 12, 14, 16, 21, 27 і 29 залишені поверхнями зварювальних планок імпульсного зварювача пакетів FRN 900, який було надано для дослідження, унаслідок запаювання цих поліетиленових пакетів.

Отже, результатом ідентифікаційних досліджень слідів на поліетиленових виробах, як правило, спочатку є встановлення їх спільної групової належності. І зі збільшенням виявлених ознак і властивостей випадкового характеру (через вплив таких чинників, як експлуатація, зношеність, пошкодження під час використання чи транспортування тощо), не передбачених технологією виготовлення таких пристроїв, зменшується зазначена група їх різновиду, а характерний індивідуальний комплекс (комплекс ідентифікаційних ознак) дає змогу ідентифікувати конкретний пристрій.

Проте вирішення ідентифікаційного завдання під час криміналістичної експертизи таких об’єктів може ускладнюватися варіаційністю їх властивостей (як-то: розтягування, зминання викривляння виробів тощо). Водночас практика проведення описаного різновиду трасологічної експертизи доводить імовірність ідентифікування приладів, якими залишені сліди термічного оброблення, за окремими (індивідуальними) ознаками

\section{Наукова новизна}

Теоретично обгрунтовано, методологічно розроблено і в конкретному експертному провадженні експериментально апробовано новий різновид трасологічної експертизи.

\section{Висновки}

1. Аргументовано на основі дослідження сучасних особливостей кримінальних правопорушень у сфері обігу наркотичних засобів та психотропних речовин у частині їх маскування i транспортування, аналізу основних положень теорії зварювання плівкових матеріалів, виготовлених із пластичних мас, і механізму утворення швів на них, а також реаліями сьогодення необхідність вдосконалення трасологічної експертизи.

2. Доведено в результаті дослідження зразків слідів термічного оброблення на пакувальних матеріалах конкретного кримінального провадження та наданого для дослідження приладу, що впровадження в експертну практику нового різновиду 
трасологічних досліджень розширить можливості розкриття злочинів у частині ідентифікування пристроїв, які залишили сліди термічного оброблення, і підвищить потенціал однієї з основоположних галузей криміналістики - трасології.

3. Узагальнено досвід проведення трасологічної експертизи в частині дослідження слідів тер- мічного оброблення на поліетиленових виробах, визначення їх походження та ідентифікування конкретних пристроїв, що залишили ці сліди, а також висловлено пропозиції, що можуть стати основою відповідних методичних рекомендацій для судових експертів експертних установ і працівників правоохоронних органів.

\section{References}

Bratychak, M. M., Chopyk, N., \& Zemke, V. M. (2018). Technological features of polymer blends processing based on ultra-high molecular weight polyethylene. Chemistry, Technology and Application of Substances, 1 (1), $127-132$. DOI: https://doi.org/10.23939/ctas2018.01.127.

Chernov, V. H., Holomisiuk, Ye. A., \& Yevsieiev, P. O. (2019). Osoblyvosti ekspertnoho doslidzhennia slidiv dii vidmychok na vnutrishnikh poverkhniakh tsylindrovykh mekhanizmiv zamkiv. Teoriia ta praktyka sudovoi ekspertyzy i kryminalistyky, 20 (2), 292-308 [in Ukrainian]. DOI: https://doi.org/10.32353/khrife.2.2019.22.

Demura, A. L. (2001). Polimerni kompozytsiini materialy [Polimer compoused matherials]. Kosmichna nauka i tekhnolohiia, 7 (Dodatok 1) [Kosm. nauka tehnol., 7 (Supplement 1)], 125-126 [in Ukrainian]. DOI: https://doi.org/10.15407/knit2001.01s.125.

Egorov, S. A. (2017). Analiz metodik nanomodifitcirovaniia polimernykh kompozitcionnykh materialov. Tendentcii razvitiia nauki i obrazovaniia, 22-4, 14-17 [in Russian]. DOI: https://doi.org/10.18411/lj-31-01-2017-4-05.

Fialko, N. M., Dinzhos, R. V., Sherenkovskii, Iu. V., Prokopov, V. G., Meranova, N. O., Navrodskaia, R. A. ... Ivanenko, G. V. (2018). Osobennosti protcessa strukturoobrazovaniia nanokompozitov na osnove polietilena pri ego napolnenii uglerodnymi nanotrubkami [in Russian]. Naukovyi visnyk NLTU Ukrainy, 28 (6), 74-80 [in Ukrainian]. DOI: https://doi.org/10.15421/40280614.

Hrabovskyi, H. V., \& Oparii, A. O. (2020). Osoblyvosti ekspertnoho doslidzhennia slidiv vzuttia ta yikh identyfikatsii. Molodyi vchenyi, 6 (82), 243-248 [in Ukrainian].

DOI: https://doi.org/10.32839/2304-5809/2020-6-82-50.

Kofanov, A. V., Voloshyn, O. H., \& Litvinova, O. V. (2010). Trasolohichni doslidzhennia: kurs lektsii. Kyiv: Kyiv. nats. un-t vnutr. sprav. 304 s. [in Ukrainian].

Kryvoshei, V. M., \& Khalaidzhi, V. V. (2019). Tendentsii rozvytku svitovoho pakuvannia. Prodovolchi resursy, 13, 95-105 [in Ukrainian]. DOI: https://doi.org/10.31073/foodresources2019-13-09.

Ling, S., Kaplan, J., \& Berryessa, C. M. (2021). The importance of forensic evidence for decisions on criminal guilt. Science \& Justice: journal of the Forensic Science Society, 61 (2), 142-149.

DOI: https://doi.org/10.1016/j.scijus.2020.11.004.

Lysenko, N. V. (2019). Tovaroznavcha ekspertyza polimernykh paketiv typu maika TOV «KOMSERV UKRAINA». Tovaroznavchyi visnyk, 1 (12), 168-175 [in Ukrainian]. DOI: https://doi.org/10.36910/6775-2310-5283-2019-12-16.

Nykyforchuk, D. Y. (2019). Tranzyt narkotykiv terytoriieiu Ukrainy yak peredumova poshyrennia narkobiznesu v Yevropi. Naukovyi visnyk Natsionalnoi akademii vnutrishnikh sprav, 2 (111), 41-48 [in Ukrainian]. DOI: https://doi.org/10.33270/01191112.41.

Rudnytskyi, I. (2017). Kryminalistychna kharakterystyka sposobiv kontrabandy narkotychnykh zasobiv, shcho yikh vchyniaiut orhanizovani zlochynni hrupy. Visnyk Natsionalnoho universytetu «Lvivska politekhnika». Seriia: Yurydychni nauky, 861, 514-521 [in Ukrainian].

DOI: https://doi.org/10.23939/law2017.861.514.

Semeniuk, N. B., Skorokhoda, T. V., \& Dudok, H. D. (2020). Feromahnitni polimerni dyspersii na osnovi metakrylovykh esteriv. Vplyv parametra rozchynnosti kompozytsii na zakonomirnosti oderzhannia. Chemistry, Technology and Application of Substances, 3 (2), 157-162 [in Ukrainian]. DOI: https://doi.org/10.23939/ctas2020.02.157.

Serdiuk, O. O., Bazyma, B. O., \& Shcherbakova, I. V. (2020). Molod ta narkotyky-2019: za rezultatamy sotsiolohichnoho monitorynhu rozpovsiudzhennia khimichnykh ta nekhimichnykh form zalezhnosti sered molodi: nauk. zvit. Kharkiv: KhNUVS. 72 s. [in Ukrainian]. DOI: https://doi.org/10.32631/dr2020.

Shulha, O., Ivanov, S., Lystopad, V., \& Mazurenko, O. (2019). Doslidzhennia teplofizychnykh kharakterystyk formuvalnoho rozchynu biodehradabelnoho yistivnoho pokryttia/plivky. Scientific Works, 82 (2), 47-55 [in Ukrainian]. DOI: https://doi.org/10.15673/swonaft.v82i2.1169.

Sidorov, D. E., Sivetskyi, V. I., Kolosov, O. Ye., Sokolskyi, O. L., \& Dudar, Zh. O. (2011). Zvariuvannia u vyhotovlenni polimernykh plivkovykh pakuvan. Visnyk Natsionalnoho tekhnichnoho universytetu Ukrainy «KPI» (Seriia «Khimichna inzheneriia, ekolohiia ta resursozberezhennia»), 2 (8), 9-16 [in Ukrainian]. 
TOV firma IVK Tekhnika: ofits. sait. (2021). Uziato z https://www.upakovka.com.ua/ukr/ [in Ukrainian].

Turianskyi, Yu. (2020). Onovlennia mizhnarodnoi paradyhmy rehuliuvannia vzhyvannia narkotykiv: do postanovky problemy. Visnyk Natsionalnoho universytetu «Lvivska politekhnika». Seriia: Yurydychni nauky, 7 (1), 83-88. DOI: https://doi.org/10.23939/law2020.25.083.

Zakurlaev, A. K. (2020). The Importance of Forensic Examination in Criminal Exposure. The American Journal of Political Science Law and Criminology, 2 (11), 125-128. DOI: https://doi.org/10.37547/tajpslc/Volume02Issue11-20.

Zulfuqorov, A. A. (2020). Explanation and classification of traces in the theory of trasological expert. European Science Review, 1-2, 144-147.

DOI: https://doi.org/10.29013/ESR-20-1.2-144-147.

Zvit shchodo narkotychnoi ta alkoholnoi sytuatsii v Ukraini za 2020 rik (za danymy 2019 roku). (2020). Kyiv. 55 s. Uziato z https://www.emcdda.europa.eu/system/files/attachments/13559/Zvit-shhodo-narkotykiv-ta-alkogolyu-za-2020-rik. pdf [in Ukrainian].

\section{Список використаних джерел}

Bratychak, M. M., Chopyk, N., \& Zemke, V. M. (2018). Technological features of polymer blends processing based on ultra-high molecular weight polyethylene. Chemistry, Technology and Application of Substances, 1 (1), 127-132. DOI: https://doi.org/10.23939/ctas2018.01.127.

Чернов, В. Г., Голомісюк, Є. А., \& Євсєєв, П. О. (2019). Особливості експертного дослідження слідів дії відмичок на внутрішніх поверхнях циліндрових механізмів замків. Теорія та практика судової експертизи і криміналістики, 20 (2), 292-308. DOI: https://doi.org/10.32353/khrife.2.2019.22.

Демура, А. Л. (2001). Полімерні композиційні матеріали [Polimer compoused matherials]. Космічна наука і технологія, 7 (Додаток 1) [Kosm. nauka tehnol., 7 (Supplement 1)], 125-126. DOI: https://doi.org/10.15407/knit2001.01s.125.

Егоров, С. А. (2017). Анализ методик наномодифицирования полимерных композиционных материалов. Тенденичи развития науки и образования, 22-4, 14-17. DOI: https://doi.org/10.18411/lj-31-01-2017-4-05.

Фиалко, Н. М., Динжос, Р. В., Шеренковский, Ю. В., Прокопов, В. Г., Меранова, Н. О., Навродская, Р. А. ... Иваненко, Г. В. (2018). Особенности процесса структурообразования нанокомпозитов на основе полиэтилена при его наполнении углеродными нанотрубками. Науковий вісник НЛТУ Украйни, 28 (6), 74-80. DOI: https://doi.org/10.15421/40280614.

Грабовський, Г. В., \& Опарій, А. О. (2020). Особливості експертного дослідження слідів взуття та їх ідентифікації. Молодий вчений, 6 (82), 243-248. DOI: https://doi.org/10.32839/2304-5809/2020-6-82-50.

Кофанов, А. В., Волошин, О. Г., \& Літвінова, О. В. (2010). Трасологічні дослідження: курс лекцій. Київ: Київ. нац. ун-т внутр. справ. 304 с.

Кривошей, В. М., \& Халайджі, В. В. (2019). Тенденції розвитку світового пакування. Продовольчі ресурси, 13, 95-105.

DOI: https://doi.org/10.31073/foodresources2019-13-09.

Ling, S., Kaplan, J., \& Berryessa, C. M. (2021). The importance of forensic evidence for decisions on criminal guilt. Science \& Justice: journal of the Forensic Science Society, 61 (2), 142-149.

DOI: https://doi.org/10.1016/j.scijus.2020.11.004.

Лисенко, Н. В. (2019). Товарознавча експертиза полімерних пакетів типу майка ТОВ «КОМСЕРВ УКРАЇНА». Товарознавчий вісник, 1 (12), 168-175.

DOI: https://doi.org/10.36910/6775-2310-5283-2019-12-16.

Никифорчук, Д. Й. (2019). Транзит наркотиків територією України як передумова поширення наркобізнесу в Європі. Науковий вісник Національної академії внутрішніх справ, 2 (111), 41-48.

DOI: https://doi.org/10.33270/01191112.41.

Рудницький, I. (2017). Криміналістична характеристика способів контрабанди наркотичних засобів, що їх вчиняють організовані злочинні групи. Вісник Національного університету «Львівська політехніка». Серія: Юридичні науки, 861, 514-521. DOI: https://doi.org/10.23939/law2017.861.514.

Семенюк, Н. Б., Скорохода, Т. В., \& Дудок, Г. Д. (2020). Феромагнітні полімерні дисперсії на основі метакрилових естерів. Вплив параметра розчинності композицій на закономірності одержання. Chemistry, Technology and Application of Substances, 3 (2), 157-162. DOI: https://doi.org/10.23939/ctas2020.02.157.

Сердюк, О. О., Базима, Б. О., \& Щербакова, І. В. (2020). Молодь та наркотики-2019: за результатами соиіологічного моніторингу розповсюдження хімічних та нехімічних форм залежності серед молоді: наук. звіт. Харків: ХНУВС. 72 c.

DOI: https://doi.org/10.32631/dr2020. 
Шульга, О., Іванов, С., Листопад, В., \& Мазуренко, О. (2019). Дослідження теплофізичних характеристик формувального розчину біодеградабельного їстівного покриття / плівки. Scientific Works, 82 (2), 47-55. DOI: https://doi.org/10.15673/swonaft.v82i2.1169.

Сідоров, Д. Е., Сівецький, В. І., Колосов, О. Є., Сокольський, О. Л., \& Дудар, Ж. О. (2011). Зварювання у виготовленні полімерних плівкових пакувань. Вісник Національного технічного університету України «КПI» (Серія «Хімічна інженерія, екологія та ресурсозбереження»), 2 (8), 9-16.

ТОВ фірма ІВК Техніка:офіц. сайт. (2021). Узято з https://www.upakovka.com.ua/ukr/.

Турянський, Ю. (2020). Оновлення міжнародної парадигми регулювання вживання наркотиків: до постановки проблеми. Вісник Національного університету «Львівська політехніка». Серія: Юридичні науки, 7 (1), 83-88. DOI: https://doi.org/10.23939/law2020.25.083.

Zakurlaev, A. K. (2020). The Importance of Forensic Examination in Criminal Exposure. The American Journal of Political Science Law and Criminology, 2 (11), 125-128. DOI: https://doi.org/10.37547/tajpslc/Volume02Issue11-20.

Zulfuqorov, A. A. (2020). Explanation and classification of traces in the theory of trasological expert. European Science Review, 1-2, 144-147.

DOI: https://doi.org/10.29013/ESR-20-1.2-144-147.

Звіт щзодо наркотичної та алкогольної ситуації в Україні за 2020 рік (за даними 2019 року). (2020). Київ. 55 с. Узято 3 https://www.emcdda.europa.eu/system/files/attachments/13559/Zvit-shhodo-narkotykiv-ta-alkogolyu-za-2020rik.pdf.

P. Tsidylo, Forensic Expert of Trasological Research Sector,

Forensic Research Department,

Lviv Scientific Research Forensic Center

MIA of Ukraine, Lviv, Ukraine

ORCID: https://orcid.org/0000-0003-0668-7184

\section{TRASOLOGICAL STUDY OF TRACES OF HEAT TREATMENT ON POLYETHYLENE PRODUCTS AND IDENTIFICATION OF DEVICES, WHAT LEFT THOSE TRACES AS A NEW KIND OF FORENSIC TRASOLOGICAL EXAMINATION}

\footnotetext{
The purpose of the article is to substantiate the expediency of initiating a trasological study of traces of heat treatment on polyethylene products and to identify the devices that left them as a new type of forensic trasological examination.Methodology. The reliability of the obtained results and conclusions is ensured by the use of general (general scientific) and special methods of cognition. The object and subject of research are chosen by the dialectical method, its purpose and tasks are substantiated; by the method of analysis and generalization the necessary substantiations on the basis of the theory of welding of polymeric films are carried out; the mechanism of formation of seams on film materials is studied by a structural-functional method; experimental methods made experimental samples of traces of heat treatment, using the method of microscopic examination studied traces of heat treatment on objects of research and experimental samples and their structure, the results of which established convergent individual (identification) features in the traces. Scientific novelty. A new type of trasological research has been theoretically substantiated, methodologically developed and experimentally tested in specific expert proceedings. Conclusions. Argued on the basis of a study of modern features of criminal offenses in the field of drugs and psychotropic substances in terms of their masking and transportation, analysis of the main provisions of the theory of welding film materials made of plastics and the mechanism of seams on them, as well as today's realities of trasological expertise. It is proved as a result of research of samples of traces of heat treatment on packing materials of concrete criminal proceedings and the device provided for research that introduction in expert practice of a new kind of trasological researches will expand possibilities of detection of crimes in part of identification of devices which have left traces of heat treatment. branches of criminology - trasology. The experience of conducting trasological examination in the study of traces of heat treatment on polyethylene products, determining their origin and identifying specific devices that left these traces, as well as suggestions that can form the basis of appropriate guidelines for forensic experts and law enforcement agencies.

Keywords: forensic trasological examination, traces of heat treatment, polyethylene products; traces of heat treatment on polyethylene products; identification of devices that have left traces of heat treatment; thermocontact and thermopulse welding; welds, drugs.
} 
П. Я. Цидыло, судебный эксперт сектора трасологического учета

отдела криминалистических видов исследований,

Львовский научно-исследовательский экспертно-

криминалистический иентр МВД Украины, г. Львов

ORCID: https://orcid.org/0000-0003-0668-7184

\title{
ТРАСОЛОГИЧЕСКОЕ ИССЛЕДОВАНИЕ СЛЕДОВ ТЕРМИЧЕСКОЙ ОБРАБОТКИ НА ПОЛИЭТИЛЕНОВЫХ ИЗДЕЛИЯХ И ИДЕНТИФИКАЦИЯ ПРИБОРОВ, ИХ ОСТАВИВШИХ, КАК НОВАЯ РАЗНОВИДНОСТЬ СУДЕБНОЙ ТРАСОЛОГИЧЕСКОЙ ЭКСПЕРТИЗЫ
}

\begin{abstract}
Цель статьи состоит в обосновании целесообразности развития трасологического исследования следов термической обработки на полиэтиленовых изделиях и идентификации приборов, их оставивших, как новой разновидности судебной трасологической экспертизы. Методология. Достоверность полученных результатов и выводов обеспечена использованием общелогических (общенаучных) и специальных методов исследования. Диалектическим методом определены объект и предмет исследования, обоснованы его цель и задачи; методом анализа и обобщения осуществлены необходимые обоснования на основе теории сварки полимерных пленок; структурно-функциональным методом изучен механизм образования швов на пленочных материалах; экспериментальным методом изготовлены экспериментальные образцы следов термической обработки; с применением метода микроскопического исследования изучены следы термической обработки на объектах исследования и экспериментальных образцах, их структура, по результатам чего установлены совпадающие отдельные (идентификационные) признаки в следах. Научная новизна. Теоретически обоснована, методологически разработана и в конкретном экспертном производстве экспериментально апробирована новая разновидность трасологической экспертизы. Выводы. Аргументирована на основе исследования современных особенностей уголовных правонарушений в сфере оборота наркотических средств и психотропных веществ в части их маскировки и транспортировки, анализа основных положений теории сварки пленочных материалов, изготовленных из пластических масс, и механизма образования швов на них, а также современными реалиями необходимость совершенствования трасологической экспертизы. Доказано в результате исследования образцов следов термической обработки на упаковочных материалах конкретного уголовного производства и предоставленного на исследование прибора, что внедрение в экспертную практику новой разновидности трасологических исследований расширит возможности раскрытия преступлений в части идентификации устройств, которые оставили следы термической обработки, и повысит потенциал одной из основополагающих отраслей криминалистики - трасологии. Обобщен опыт проведения трасологической экспертизы в части исследования следов термической обработки на полиэтиленовых изделиях, установления их происхождения и идентификации конкретных устройств, оставивших эти следы, а также высказаны предложения, которые могут стать основой соответствующих методических рекомендаций для судебных экспертов экспертных учреждений и работников правоохранительных органов.

Ключевые слова: судебная трасологическая экспертиза; следы термической обработки; полиэтиленовые изделия; следы термической обработки на полиэтиленовых изделиях; идентификация приборов, оставивших следы термической обработки; термоконтактная и термоимпульсная сварка; сварные швы; наркотические средства.
\end{abstract}

